\title{
Prenatal diagnosis of $\beta$ thalassaemia based on restriction endonuclease analysis of amplified
} fetal DNA

\author{
M PIRASTU*, M S RISTALDI*, AND A CAO† \\ From * Istituto di Ricerca sulle Talassemie ed Anemie Mediterranee CNR; and †Istituto di Clinica e Biologia \\ dell'Età Evolutiva, Università degli Studi di Cagliari, Cagliari, Sardinia, Italy.
}

SUMmaRY In the Mediterranean area, $50 \%$ of the $\beta$ thalassaemia mutations abolish or create a restriction endonuclease site in the $\beta$ globin gene. This study describes a new procedure for prenatal detection of these $\beta$ thalassaemia defects based on the direct visualisation, on an ethidium bromide stained polyacrylamide gel, of the discrete DNA fragments produced by restriction endonuclease digestion of fetal DNA, enzymatically amplified using the DNA polymerase from the thermophilus bacterium Thermus aquaticus. We applied this procedure to the Sardinian population to detect the nonsense mutation at codon 39 and the frameshift at codon 6 of the $\beta$ globin gene; these are the most frequent $\beta$ thalassaemia mutations in this population, accounting for $95 \%$ and $2 \cdot 2 \%$ of the $\beta$ thalassaemia chromosomes. The main advantages of this procedure are simplicity (no radioactivity), sensitivity ( $0.2 \mu \mathrm{g}$ of DNA), and rapidity (12 hours). The very small amount of fetal material required makes amniotic fluid cell culture unnecessary and may decrease the fetal loss rate associated with trophoblast sampling. By circumventing the use of radioactive and non-radioactive probes, the spread of this technology to the high risk areas will be facilitated.

Prenatal diagnosis of $\beta$ thalassaemia is nowadays accomplished by fetal DNA analysis. ${ }^{1}$ The methods currently used are based on the direct detection of $\beta$ thalassaemia mutations by restriction endonuclease analysis $^{23}$ and oligonucleotide hybridisation ${ }^{4-8}$ or on indirect identification by linkage analysis with restriction fragment length polymorphisms (RFLPs) in the $\beta$ globin gene cluster. ${ }^{1}$ These methods require a relatively large amount of DNA $(>3 \mu \mathrm{g})$, which may, in part, be responsible for the high risk $(3.5 \%)^{9} 10$ of fetal mortality associated with trophoblast sampling and for the delay in diagnosis when cultured amniocytes have to be analysed. A new method, based on dot blot analysis of enzymatically amplified $\beta$ globin gene sequences and hybridisation with allelic specific oligonucleotide probes, has recently been proposed for the detection of sickle cell anaemia. ${ }^{\text {II }}$ This method is sensitive enough to detect allelic variations with as little as $0.001 \mu \mathrm{g}$ genomic DNA, but still depends on the use of radiolabelled oligonucleotide probes. Lately, detection of sickle cell anaemia has been accom-

Received for publication 3 August 1988.

Revised version accepted for publication 2 December 1988. plished by a technique in which the amplified target DNA sequence is digested with the restriction enzyme affected by the mutation and then directly visualised on an ethidium bromide stained polyacrylamide gel as separate DNA fragments, ${ }^{12}$ thus avoiding the use of molecular probes.

This study describes a similar approach for the prenatal diagnosis of $\beta$ thalassaemia mutations affecting a restriction enzyme site, which account for $50 \%$ of the $\beta$ thalassaemia defects in the Mediterranean area. In Sardinia we applied this procedure to detect the nonsense mutation at codon $39\left(\beta^{\circ} 39\right)^{13}$ and the frameshift at codon $6\left(\beta^{\circ} 6\right),{ }^{214}$ which are the most frequent $\beta$ thalassaemia defects in this region, accounting for $95 \%$ and $2 \cdot 2 \%$ of the $\beta$ thalassaemia chromosomes. ${ }^{15}$ This method is sufficiently sensitive and rapid to allow prenatal diagnosis 12 hours after fetal DNA sampling. The very small amount of genomic DNA necessary for this assay overcomes the need for amniocyte culture and reduces the risk of fetal loss associated with trophoblast sampling. In countries where thalassaemia is frequent, this method may assist the application of DNA analysis to prenatal diagnosis which has been 
limited so far by the need for radiolabelled molecular probes.

\section{Material and methods}

Genomic DNA was extracted from peripheral blood, chorionic villus biopsy, and amniocytes by standard techniques. ${ }^{16} \mathrm{~A}$ crude amniocyte lysate was prepared as follows: $1 \mathrm{ml}$ of amniotic fluid, withdrawn at 16 weeks of pregnancy, was centrifuged for 10 hours at $3000 \mathrm{rpm}$; the pellet was frozen and thawed and then resuspended in sterile water and left at $95^{\circ} \mathrm{C}$ for 15 minutes.

DNA amplification was carried out with two oligonucleotide primers, one ( $R$ primer) complementary to the coding strand of the $\beta$ globin gene from codons 83 to 90 , the other (L primer) complementary to the anticoding strand from position -76 to $-565^{\prime}$ to the Cap site (fig 1a). The sequences of the primers are: $\mathrm{L}=5^{\prime} \mathrm{CCAATCTACTCCCAGGAGCA} 3^{\prime}, \mathrm{R}=5^{\prime}$ CACTCAGTGTGGCAAAGGTG $3^{\prime}$. These two primers allow us to amplify specifically a segment of the $\beta$ globin gene which includes the $5^{\prime}$ untranslated region, the first exon, the first intervening sequence, and almost all the second exon; this region contains the majority of the known $\beta$ thalassaemic defects. However, the two primers are not able to amplify the corresponding region of the $\delta$ globin gene, since they have several mismatches with this gene.

Genomic DNA was amplified ${ }^{17} 18$ as follows: to $100 \mu$ l final volume we added $1 \mu \mathrm{g}$ of total genomic DNA or a crude amniocyte lysate from $1 \mathrm{ml}$ of amniotic fluid, 100 pmol of each primer ( $L$ and $R$ ), the four nucleotides (dATP, dGTP, dTTP, dCTP) at a final concentration of $1.5 \mathrm{mmol} / \mathrm{l}$ each, 6.6 $\mathrm{mmol} / \mathrm{l}$ ammonium sulphate, $67 \mathrm{mmol} / \mathrm{l}$ tris $\mathrm{HCl}$ $(\mathrm{pH} 8.8), 6.7 \mathrm{mmol} / \mathrm{l} \mathrm{MgCl}, 10 \mathrm{mmol} / \mathrm{l} \beta$ mercaptoethanol, $170 \mu \mathrm{g} / \mathrm{ml}$ bovine serum albumin, and $10 \%$ dimethyl-sulphoxide.

DNA denaturation was carried out for seven minutes at $95^{\circ} \mathrm{C}$; afterwards the sample was left for five minutes at room temperature for the hybridisation between the primers and their target DNA sequences. Then two units of thermostable DNA polymerase $^{19}$ (Taq Polymerase, New England Biolabs) was added and the primer extension continued for five minutes at $55^{\circ} \mathrm{C}$. This was followed by 24 cycles of denaturation-hybridisationextension at $91^{\circ} \mathrm{C}$ for 60 seconds, room temperature for 60 seconds, and at $55^{\circ} \mathrm{C}$ for five minutes, respectively. Every 10 cycles, two more units of Taq Polymerase were added.

After 25 cycles of amplification, which takes about three hours, the DNA was phenol extracted, ethanol precipitated, and resuspended in TE buffer
( $1 \mathrm{mmol} / \mathrm{l}$ Tris- $\mathrm{HCl}, \mathrm{pH} 7 \cdot 4,0 \cdot 1 \mathrm{mmol} / 1$ EDTA, $\mathrm{pH}$ 8). One-third of the amplified DNA was digested for three hours with 20 units of the appropriate restriction enzyme in the assay condition recommended by the supplier. The digested DNA, after adding $5 \mu \mathrm{l}$ of loading dye $(0 \cdot 2 \%$ Bromo phenol blue, $0 \cdot 2 \%$ Xilen-cyanol, $80 \%$ glycerol), was loaded on a $5 \%$ polyacrylamide gel in a vertical apparatus. Electrophoresis was carried out at 500 volts for 40 minutes in TBE buffer $(0.089 \mathrm{~mol} / \mathrm{l}$ Trisborate, $0.089 \mathrm{~mol} / \mathrm{l}$ boric acid, 0.002 mol/l EDTA). The gel was stained for 10 minutes with ethidium bromide $(1 \mu \mathrm{g} / \mu \mathrm{l})$ and the DNA fragments were then visualised on a UV transilluminator and photographed with a Polaroid camera.

\section{Results}

\section{DETECTION OF THE $\beta^{\circ} 39$ MUTATION}

In the normal $\beta$ globin gene $(\beta A$, fig $1 a)$ the amplified region, 527 nucleotides (nt) long, between the two primers $\mathrm{L}$ and $\mathrm{R}$, contains one MaeI site at nucleotide $293^{\prime}$ to the Cap site, while an additional MaeI site is created by the nonsense mutation at codon 39 in the $\beta$ thalassaemic gene $\left(\beta^{\circ} 39\right.$, fig $\left.1 \mathrm{a}\right)$. Fig $1 \mathrm{~b}$ shows an ethidium bromide stained polyacrylamide gel after electrophoresis of the MaeI digested amplified genomic DNA from a normal subject (lane 3), a heterozygote (lane 2), and a homozygote (lane 1) for the $\beta^{\circ} 39$ mutation. The normal subject $(\beta A / \beta A)$ shows a $422 \mathrm{nt}$ fragment, whereas in the $\beta$ thalassaemia homozygote $\left(\beta^{\circ} 39 / \beta^{\circ} 39\right)$ this fragment is replaced by two new 268 and 154 nt fragments. The heterozygote $\left(\beta^{\circ} 39 / \beta A\right)$ is defined by the presence of the $422 \mathrm{nt}$ fragment from the normal gene and the 268 and 154 nt fragments from the mutated gene. The absence of the $527 \mathrm{nt}$ fragment and the presence of the $105 \mathrm{nt}$ fragment in all the MaeI digested amplified DNA indicate the completeness of the digestion.

\section{DETECTION OF THE $\beta^{\circ} 6$ MUTATION}

Fig 1 shows the OxaNI map in the region between the same primers used for the identification of the $\beta^{\circ} 39$ mutation. This region in the normal $\beta$ globin gene $(\beta \mathrm{A})$ contains three $O x a \mathrm{NI}$ sites, at codon 6 , at nucleotide 125 in the first intervening sequence, and at codon 58. Since the $\beta^{\circ} 6$ mutation removes the OxaNI site at codon 6, only the other two normal of sites are present in the $\beta^{\circ} 6$ mutated gene. Fig $1 d$ shows an ethidium bromide stained polyacrylamide gel after electrophoresis of $O x a \mathrm{NI}$ digested amplified DNA from a normal subject (lane 3), a heterozygote (lane 2), and a homozygote (lane 1) for the $\beta^{\circ} 6$ mutation. As expected, the normal 


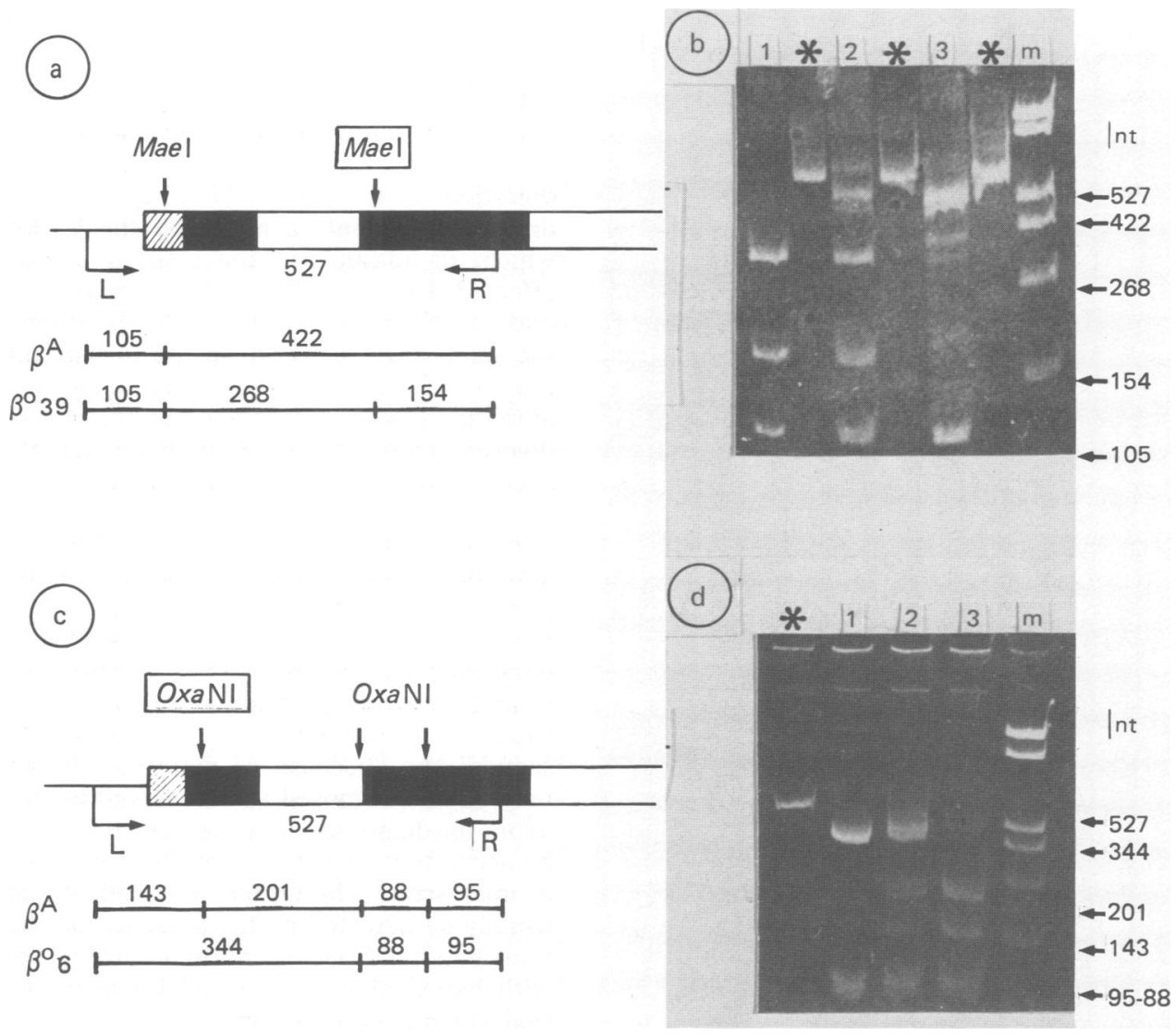

FIG 1 Detection of the $\beta^{\circ} 39$ and $\beta^{\circ} 6$ mutations by restriction endonuclease digestion of amplified DNA. In (a) and (c) the MaeI and $O x a N I$ sites in the amplified region are shown. The sites affected by the mutations are framed. The numbers indicate the nucleotides. (b) and (d) show ethidium bromide stained polyacrylamide gels after electrophoresis of MaeI and OxaNI digested amplified DNA respectively. The asterisks indicate the lanes where undigested amplified DNA was loaded. The molecular weight marker is in lane $m$.

subject $(\beta A / \beta A)$ is defined by the presence of the 201 and $143 \mathrm{nt}$ fragments, while their absence and substitution by the $344 \mathrm{nt}$ fragment are characteristic of the $\beta$ thalassaemia homozygote $\left(\beta^{\circ} 6 / \beta^{\circ} 6\right)$. Obviously all these three fragments are present in the heterozygote $\left(\beta^{\circ} 6 / \beta A\right)$. The 95 and $88 \mathrm{nt}$ fragments, which cannot be separated in our experimental conditions, are shown in all three samples and together with the lack of the $527 \mathrm{nt}$ band indicate a complete OxaNI digestion.

\section{PRENATAL DIAGNOSIS}

We have so far monitored by this method 14 pregnancies at risk for $\beta^{\circ} 39$ thalassaemia and one for the compound heterozygous state for the $\beta^{\circ} 39$ and $\beta^{\circ} 6$ mutations. The results obtained were confirmed by oligonucleotide analysis carried out at the same time. In fig 2 examples of prenatal diagnosis by amniocyte or trophoblast DNA analysis of normal (lane 5), heterozygous (lanes 1,2, and 4), and homozygous (lane 3 ) fetuses for the $\beta^{\circ} 39$ mutation are shown. The method is very sensitive since it allows us to detect the mutation with as little as $0.2 \mu \mathrm{g}$ of genomic DNA, and is very rapid, the result being obtained within 12 hours of the sampling of fetal material. The DNA from as small a number of amniocytes as those contained in $1.0 \mathrm{ml}$ of amniotic fluid was also successfully amplified without previous DNA extraction and analysed by this method. 


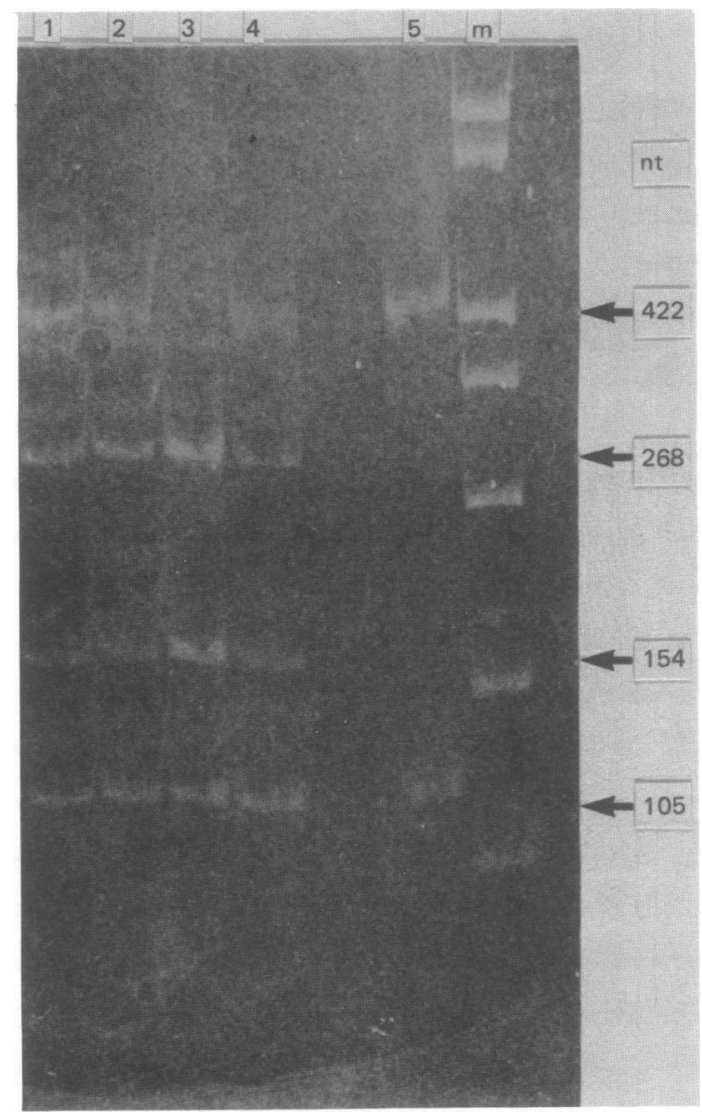

FIG 2 Prenatal diagnosis of the $\beta^{\circ} 39$ mutation by MaeI digestion of amplified fetal DNA.

\section{Discussion}

This study shows that prenatal detection of $\beta$ thalassaemia mutations affecting a restriction endonuclease site can be accomplished by direct visualisation under ultraviolet light on an ethidium bromide stained polyacrylamide gel, after electrophoresis, of the discrete DNA fragments produced by restriction endonuclease digestion of enzymatically amplified globin gene sequences. In our experience, which agrees with previously described studies, ${ }^{12} 20$ the use of the thermostable DNA polymerase was crucial for obtaining these results. The assay conditions, such as high temperature, required for the optimal activity of the DNA polymerase, increase the specific annealing of the two oligonucleotide primers with their complementary sequences in the genomic DNA. Thus, a large amount of pure target DNA fragment is $\stackrel{\overparen{D}}{=}$ obtained.

One of the problems encountered in prenatal diagnosis using restriction endonuclease analysis is the possibility of misdiagnosis owing to incomplete $\frac{\bar{\sigma}}{\overline{0}}$ digestion of the fetal DNA by the enzyme. We $\vec{\nabla}$ decided to amplify a region of the $\beta$ globin gene $\propto$ which, in addition to the restriction enzyme site affected by the $\beta^{\circ} 39$ and $\beta^{\circ} 6$ mutations (MaeI $\vec{\circ}$ and $O x a$ NI respectively), includes other sites for the same enzymes, both in the normal and in the $\vec{\omega}$ mutated genes. Thus, complete digestion of the amplified DNA is guaranteed by the lack of the un- $\overline{0}$ digested amplified fragment independently of the specific fragment pattern determined by the presence or the absence of the mutation. The possibility $\omega$ of monitoring the restriction enzyme digestion of the $\mathscr{\mathscr { W }}$ amplified DNA improves the reliability of this method. In the detection of specific $\beta$ thalassaemia mutations by the procedure described here on $ᄃ$ enzymatically amplified DNA, a potential problem is maternal cell contamination. The most critical ${ }_{\overrightarrow{0}}$ situation regards fetuses homozygous for $\beta$ thalas- $\oplus$ saemia who, because of maternal contamination,.$\oplus$ may be misdiagnosed as heterozygotes. In order to avoid misdiagnosis, first the placental tissue should be accurately dissected from the trophoblasts under a microscope. Maternal cell contamination can usually be detected by the presence on the gel of $a \stackrel{\Phi}{\Phi}$ faint band(s) from the normal chromosome, along $\overrightarrow{\vec{P}}$ with bands of more marked intensity from the $\beta \frac{0}{3}$ thalassaemia chromosomes.

The main advantages of this procedure are simplicity, sensitivity, and rapidity. Molecular probes are no longer necessary, making this method $\overline{0}$ very suitable even for routine laboratories. Avoid--: ing radioactive and non-radioactive probes may 3 allow prenatal diagnosis by DNA analysis to be extended to those places where thalassaemia is 3 frequent and the purchase of radioactive material is $\mathrm{O}$ difficult. DNA amplification using thermostable DNA polymerase produces a $10^{6}$-fold increase in theo amount of target sequences. This allows us to carry out prenatal diagnosis with as little as $0.2 \mu \mathrm{g}$ of DNA $\tilde{N}$ and to obtain the result very rapidly, approximatelyn within 12 to 24 hours of the fetal sampling.

The application of this method to amniocyte $e_{O}^{\omega}$ DNA analysis is extremely useful as cell culture is no longer necessary, thus reducing the time required? for the diagnosis from four weeks to a few days. The successful amplification from a crude cell lysateprepared from as little as $1.0 \mathrm{ml}$ of amniotic fluido further simplifies the procedure, eliminating the step of DNA preparation.

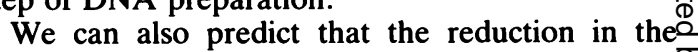
amount of fetal material necessary for the analysis? 
may result in a decrease in the risk of fetal loss associated with trophoblast sampling. In this study we amplified a region of the $\beta$ globin gene which contains the large majority of the known $\beta$ thalassaemia mutations, including the $\beta^{\circ} 39$ and $\beta^{\circ} 6$ mutations, the former being the most frequent $\beta$ thalassaemia mutation in the western part of the Mediterranean area. ${ }^{21} 22$ In Sardinia these two mutations account for $95 \%$ and $2 \cdot 2 \%$ respectively of the $\beta$ thalassaemia defects. ${ }^{15}$ Thus, the use of the procedure described here facilitates prenatal diagnosis in the vast majority of the cases. So far we have carried out successful prenatal diagnosis in 15 pregnancies at risk. In other Mediterranean countries, the use of this method makes the direct identification of nine ${ }^{2} 14^{23-27}$ thalassaemia mutations possible. These account for $50 \%$ of the $\beta$ thalassaemia chromosomes in this high risk area. The remaining mutations may be indirectly identified by linkage analysis with RFLPs detected using the same procedure, such as shown for haemophilia A. ${ }^{20}$ The direct detection of genetic defects and RFLPs by restriction endonuclease digestion of amplified DNA has broad applications in the field of prenatal diagnosis, since it may be applied to all those genetic diseases in which the molecular basis has been elucidated or closely linked RFLPs have been identified.

We thank Dr G Monni for providing the fetal samples, C Rosatelli, M T Scalas, and A Di Tucci who carried out the oligonucleotide analyses, and $R$ Lampis for providing us with the oligonucleotides. We also thank Paola Mameli for typing the manuscript and Sally Camba for the editorial review. This work was supported by Progetto Finalizzato 833 from Assessorato Igiene e Sanità Regione Autonoma della Sardegna.

\section{References}

1 Cao A, Pirastu M, Rosatelli C. The prenatal diagnosis of $\beta$ thalassaemia. Br J Haematol 1986;63:215-20.

2 Chang JC, Alberti A, Kan YW. A $\beta$ thalassaemia lesion abolishes the same MstII site as the sickle mutation. Nucleic Acids Res 1983;11:7789-94.

3 Weatherall DJ, Sampietro M, Fiorelli G. Direct detection of $\beta^{\circ} 39$ thalassaemia mutation with Mael digestion. Lancet 1985 ;i: 1095.

4 Orkin SH, Markham AF, Kazazian HH. Direct detection of the common Mediterranean $\beta$ thalassaemia gene with synthetic DNA probes. An alternative approach for prenatal diagnosis. J Clin Invest 1983;71:775-9.

5 Pirastu M, Kan YW, Cao A, Conner BJ, Teplitz RL, Wallace RB. Prenatal diagnosis of $\beta$-thalassemia. Detection of a single nucleotide mutation in DNA. N Engl J Med 1983;309:284-7.

6 Rosatelli C, Falchi AM, Scalas MT, et al. Prenatal diagnosis of $\beta$ thalassaemia with the synthetic oligomer technique. Lancet 1985 ;ii:241-3.

7 Thein SL, Waincoat JS, Old JM. Feasibility of prenatal diagnosis of $\beta$ thalassaemia with synthetic DNA probes in two Mediterranean populations. Lancet 1985;ii:345-7.
${ }^{8}$ Loi A, Pirastu M, Cao A, Ulbridh R, Hansman I. Prenatal diagnosis of the most common Mediterranean $\beta$ thalassaemia mutants by the oligonucleotide technique. Lancet 1986;i:274.

9 Williamson R, Eskdale J, Coleman DV, Niazi M, Loeffler FE, Modell B. Direct gene analysis of chorionic villi: a possible technique for first trimester antenatal diagnosis of haemoglobinopathies. . Lancet 1981 ;ii:1125-7.

${ }^{10}$ Modell B. Chorionic villus sampling: evaluating safety and efficacy. Lancet 1985;i:737-40.

"Saiki RK, Bugawan TL, Horn T, Mullis KB, Erlich HA. Analysis of enzymatically amplified $\beta$ globin and HLA-DQ DNA with allele specific oligonucleotide probes. Nature 1986; 324:163-6.

12 Chehab FF, Doherty M, Cai S, Kan YW, Cooper S, Rubin EM. Detection of sickle cell anaemia and thalassaemia. Nature 1987;329:293-4.

13 Trecartin RF, Liebhaber SA, Chang JC, et al. $\beta^{\circ}$ thalassaemia in Sardinia is caused by a nonsense mutation. J Clin Invest $1981 ; 68: 1012-7$

14 Kazazian HH Jr, Orkin SH, Boehm CD, Sexton JP, Antonarakis SE. $\beta$ thalassemia due to deletion of the nucleotide which is substituted in sickle cell anemia. Am J Hum Genet 1983;35: 1028-33.

15 Rosatelli C, Leoni 'GB, Tuveri T, Scalas MT, Di Tucci A, Cao A. $\beta$ thalassaemia mutations in Sardinians: implications for prenatal diagnosis. $J$ Med Genet 1987;24:97-100.

16 Goossens M, Dumez Y, Kaplan L, et al. Prenatal diagnosis of sickle cell anemia in the first trimester of pregnancy. $N$ Engl $J$ Med 1983;309:831-3.

17 Saiki RK, Scharf S, Faloona F, et al. Enzymatic amplification of $\beta$ globin genomic sequences and restriction site analysis for diagnosis of sickle cell anemia. Science 1985;230:1350-4.

18 Mullis KB, Faloona FA. Specific synthesis of DNA in vitro via a polymerase-catalized chain reaction. Methods Enzymol 1987; 155:335-52.

19 Chien A, Edgar DB, Trela JM. Deoxyribonucleic acid polymerase from the extreme thermophilus thermus acquaticus. $J$ Bacteriol 1976;127:1550-7.

20 Kogan CS, Doherty M, Gitschier J. An improved method for prenatal diagnosis of genetic disease by analysis of amplified DNA sequences. $N$ Engl J Med 1987;317:985-90.

${ }^{21}$ Chibani J, Vidaud M, Duquesnoy $\mathrm{P}$, et al. The peculiar spectrum of $\beta$-thalassaemia genes in Tunisia. Hum Genet 1988;78:190-2.

22 Coutinho-Gomes MP, Gomes da Costa MG, Braga LB, et al. $\beta$ thalassaemia mutations in the Portuguese population. Hum Genet 1988;78:13-15.

${ }^{23}$ Baird M, Driscoll C, Scheriner $\mathrm{H}$, et al. A nucleotide change at a splice junction in the human $\beta$ globin gene is associated with $\beta^{\circ}$ thalassemia. Proc Natl Acad Sci USA 1981;78:4218-21.

24 Orkin SH, Kazazian HH, Antonarakis SE, et al. Linkage of $\beta$ thalassaemia mutations and $\beta$ globin gene polymorphisms with DNA polymorphisms in human $\beta$ globin gene cluster. Nature 1982;296:627-31.

25 Arous N, Galacteros F, Fessas P, et al. Hemoglobin Knossos, $\beta^{27} \mathrm{Ala} \rightarrow$ Ser presenting as a silent $\beta$ thalassemia. FEBS Lett 1983;147:247-50.

26 Gilman JG, Huismann THJ, Stojanouski N, Efremov GD. Characterization of the $\beta^{+}$thalassemia mutation in a homozygous Yugoslavian patient. Hemoglobin 1984;8:529-33.

27 Feingold EA, Collins FS, Metherall JE, Stockert CJ Jr, Weissman SM, Forget BG. Molecular analysis of deletion and deletion hereditary persistence of fetal hemoglobin and identification of a new mutation causing $\beta$-thalassemia. Ann NY Acad Sci $1985 ; 445: 159-69$.

Correspondence to Professor Antonio Cao, Istituto di Clinica e Biologia dell'Età Evolutiva, Via Jenner s/n, 09100 Cagliari, Sardinia, Italy. 